\title{
5-Aminolevulinic Acid (5-ALA): Analysis of Preclinical and Safety Literature
}

\author{
Michael H. Perez ${ }^{1 *}$, Beatriz L. Rodriguez ${ }^{1,2}$, Terry T. Shintani ${ }^{1}$, Keitaro Watanabe ${ }^{3}$, Setsuko Miyanari ${ }^{3}$, \\ Rosanne C. Harrigan ${ }^{1}$
}

${ }^{1}$ Department of Complementary and Alternative Medicine, John A. Burns School of Medicine, University of Hawaii at Manoa, Honolulu, USA; ${ }^{2}$ Department of Geriatric Medicine, John A. Burns School of Medicine, University of Hawaii at Manoa, Honolulu, USA; ${ }^{3}$ Cosmo Oil Co. Ltd., Tokyo, Japan.

Email: ${ }^{*}$ mhperez@hawaii.edu

Received August $3^{\text {rd }}, 2013$; revised September $3^{\text {rd }}, 2013$; accepted September $10^{\text {th }}, 2013$

Copyright (C) 2013 Michael H. Perez et al. This is an open access article distributed under the Creative Commons Attribution License, which permits unrestricted use, distribution, and reproduction in any medium, provided the original work is properly cited.

\begin{abstract}
Problem: 5-ALA has been used for many years at relatively high dose amounts in single doses for photodynamic therapy and immunofluorescence of tumors. An analysis of compiled data relating to safety and any side-effects about the use of 5-ALA at low doses has not yet been published. Purpose: This report analyzes data about the safety of the use of 5-Aminolevulinic Acid (5-ALA) in low doses as a supplement over an extended period of time. Methods: This investigation is a systematic analysis of the current literature ((Medline, and SBI) and snowballing techniques) related to the safety and efficacy of 5-ALA in animals and humans. Clinical trials in progress using 5-ALA were also analyzed. Constant comparative analyses were used to synthesize the findings. Results: The safety of low-dose 5-ALA as a supplement has been demonstrated by animal and human studies. The results suggest that none of the investigations document the presence of symptoms or abnormal laboratory results of clinical significance. The minor laboratory changes documented were judged not clinically significant.
\end{abstract}

Keywords: Photodynamic Therapy; 5-Aminolevulinic Acid; Heme; Safety

\section{Introduction}

Previously, 5-ALA has been used for many years at relatively high dose (1000 to $2000 \mathrm{mg} /$ day) in single doses for photodynamic therapy and immunofluorescence of tumors. 5-ALA at low doses (between 2.5 to $50 \mathrm{mg} /$ day) is currently being used as a dietary supplement in Japan. An analysis of compiled data relating to safety and any sideeffects about of the use of 5-ALA at low doses has not yet been published. It is a natural non-alpha amino acid. 5-ALA is a delta amino acid and is not a component of protein. As seen in Table 1, it is found in many common foods and fermented products such as spinach, tomatoes, wine, sake, etc.

5-ALA is synthesized in the mitochondria. It is a building block of protoporphyrin and a precursor of both chlorophyll and heme. The safety of 5-ALA combined with iron in a supplement at low doses has been demonstrated by animal and human studies. 5-ALA has been associated with the origin of life. There are three fundamental components:

${ }^{*}$ Corresponding author.
Nucleotides $\rightarrow$ Genetic Information;

Amino Acids $\rightarrow$ Structure \& Metabolism;

5-ALA $\rightarrow$ Energy Conversion.

\section{5-ALA Facts}

The blood concentration of 5-ALA in normal human beings is approximately $50 \mu \mathrm{g} / \mathrm{L}$. The typical intake from food is approximately $1-2 \mathrm{mg} /$ day. Five-ALA is synthesized by the body at a rate of $600 \mathrm{mg} /$ day [1]. About $1 \mathrm{mg}$ of 5-ALA is in plasma [2]. Normal plasma level in 5-ALA was $92 \mathrm{nmol} / 1(\mathrm{SD}=39, \mathrm{n}=89$ with a range of 24 - $270 \mathrm{nmol} / \mathrm{l})$ [2].

The internal heme pool has about $60 \mathrm{~g}$ in hemoglobin and $8 \mathrm{~g}$ in other heme enzymes. Five-ALA is excreted in the urine and as bilirubin at a rate of $2 \mathrm{mg} /$ day. The bioavailability is $100 \%\left(D_{i . v} / D_{\text {p.o }}\right)$. The $t_{\max }$ in plasma is $0.76 \mathrm{~h}$ and the $\mathrm{t}_{1 / 2}$ in plasma is $0.92 \mathrm{~h}$ as estimated from a sample of healthy human (18 - $55 \mathrm{y} / \mathrm{o})$ males, $\mathrm{N}=12$, given $20 \mathrm{mg} / \mathrm{kg}$ of 5-ALA [2].

The oral 5-ALA product used in all of the safety studies were produced by Cosmo Oil Co. Ltd. The supplement 
Table 1. Common foods that contain 5-ALA. As can be seen from a review of the above table, 5-ALA is found in many common foods.

\begin{tabular}{|c|c|c|}
\hline FOOD & 5-ALA content & \\
\hline Spinach & 0.18 & $\mathrm{mg} / \mathrm{kg}$ \\
\hline Green pepper & 0.23 & $\mathrm{mg} / \mathrm{kg}$ \\
\hline Tomato & 0.13 & $\mathrm{mg} / \mathrm{kg}$ \\
\hline Shitake mushroom & 0.6 & $\mathrm{mg} / \mathrm{kg}$ \\
\hline Potato & 0.12 & $\mathrm{mg} / \mathrm{kg}$ \\
\hline Banana & 0.4 & $\mathrm{mg} / \mathrm{kg}$ \\
\hline Squid & 0.5 & $\mathrm{mg} / \mathrm{kg}$ \\
\hline Octopus & 1 & $\mathrm{mg} / \mathrm{kg}$ \\
\hline \multicolumn{3}{|l|}{$\begin{array}{c}\text { FERMENTED } \\
\text { PRODUCTS }\end{array}$} \\
\hline Shochu lees & 70 & $\mathrm{mg} / \mathrm{kg}$ \\
\hline Sake lees & 26 & $\mathrm{mg} / \mathrm{kg}$ \\
\hline Baker's yeast & 140 & $\mathrm{mg} / \mathrm{kg}$ \\
\hline Wine & $1.4-2.2$ & $\mathrm{mg} / \mathrm{L}$ \\
\hline Vinegar & $0.1-5$ & $\mathrm{mg} / \mathrm{L}$ \\
\hline Sweet sake & $0.4-6$ & $\mathrm{mg} / \mathrm{L}$ \\
\hline Sake for cooking & $0.3-13$ & $\mathrm{mg} / \mathrm{L}$ \\
\hline Sake & $0.9-4.5$ & $\mathrm{mg} / \mathrm{L}$ \\
\hline Soy sauce & 0.3 & $\mathrm{mg} / \mathrm{L}$ \\
\hline
\end{tabular}

contains 3 components:

1) 5-Aminolevulinic Acid (5-ALA) phosphate salt;

2) Citric iron;

3) Corn starch (as a filler).

It is a Non-Genetically Modified Organism (GMO), Bovine Spongiform Encephalopathy (BSE) free, alcohol free and the products are manufactured under food Good Laboratory Practice (GLP) conditions. A certificate of analysis is available. No heavy metals in the analyses $(\mathrm{Pb}$, $\mathrm{As}, \mathrm{Hg}, \mathrm{Cd})$ were detected and a microbial analysis revealed viable bacterial counts $<300 / \mathrm{g}$. Neither $E$. coli or $S$. aureus were detected $[3,4]$.

\section{Photodynamic Therapy}

Cancer Treatment Photodynamic Therapy is a non-conventional light therapy for the treatment of cancer. Photodynamic therapy, also known as PDT, uses photosensitive drugs (5-ALA, Foscan, Metvix, Tookad, WST09, WST11, Photofrin and Visudyne) which are triggered by light from a specific wavelength, usually red or infrared, on the light spectrum chart [5]. Depending on the type of cancer being treated, the medications are administered differently. A singlet oxygen molecule will form when the light is applied to the drug, this molecule attacks the tumor and destroys it from the inside out. Photodynamic therapy is a proven alternative treatment for many cancers. Clinical trials have taken place worldwide and several hospitals offer PDT as a primary cancer treatment [6]. This is a high dose therapy. The high dose amount used in PDT is 20 $\mathrm{mg} / \mathrm{kg}$, or about 1000 to $2000 \mathrm{mg}$, a day. In these trials, the low dose administration of 5-ALA ranged from $25 \mathrm{mg}$ to $75 \mathrm{mg} /$ day (see Table 2) for human participants. At high doses, phototoxicity has been reported. No phototoxicity, as seen in Table 3, has been reported at low doses which are similar to concentrations found in many common foods.

Photodynamic detection is the use of photosensitive drugs with a light source of the right wavelength to detect cancer. Treatment possibilities include-prostate cancer, breast cancer, Giant Basal Cell Carcinoma (BCC) (Skin), cervical cancer, recurrent bladder cancer, vulvar cancer, brain cancer (human glioblastoma), HPV-induced cancers, colon cancer, leukemia, Barrett's esophagus, lung cancer, stomach cancer, head and neck cancers, squamous cell carcinoma (SCC), Bowen's disease, penile and other types of cancer.

Until recently 5-ALA was difficult and costly to produce. Using 5-ALA to treat cancer was a preferred alternative to ionizing radiation therapy due to the risks associated with radiation exposure.

\section{Studies Completed}

Preclinical and Safety Tests suggest that 5-ALA is safe at modest doses. A summary of these findings from investigations conducted by Cosmo Oil \& SBI can be seen in Tables 2 and 4 [7,8]. In these studies, 3 different doses of 5-Aminolevulinic acid (5-ALA) phosphate, Sodium Ferrous Citrate (SFC) and Corn starch as filler were tested in humans. The steps were: $25 \mathrm{mg}$ of 5-ALA/29 mg Sodium Ferrous Citrate (SFC) in step 1,50 mg 5-ALA/58 mg SFC in step 2 and $75 \mathrm{mg} 5$-ALA/87 $\mathrm{mg}$ SFC in step 3 (See Table 2). Twenty-two participants (11 male and 11 female) in each step (total 66 subjects) took test food supplement for 4 weeks. Participants were healthy adults. This particular investigation used higher dosages than used in the 3 investigations that occurred in Hawaii. The investigations in Hawaii used a high dose of $50 \mathrm{mg}$ /day. The safety of the test food supplement was evaluated by subjective symptoms and the clinical examination of subjects in the intake period. The change of laboratory test data were evaluated by using the one-sample t-test about the mean value of measurements obtained at 2 weeks and 4 weeks after administration, and 2 weeks after the end of the follow-up period, compared to those obtained just before the start of administration.

Adverse effects were noted in 19 subjects (6 subjects in 
Table 2. The high dose amount used in PDT is $20 \mathrm{mg} / \mathrm{kg}$, or about 1000 to $2000 \mathrm{mg}$, a day. In the trials listed here, the low dose administration of 5-ALA ranged from $25 \mathrm{mg}$ to $75 \mathrm{mg} /$ day for human participants.

\begin{tabular}{|c|c|c|c|c|c|}
\hline Type of Study & Species & $\begin{array}{c}\text { Method of } \\
\text { Administration }\end{array}$ & $\begin{array}{l}\text { Duration of } \\
\text { Dosing }\end{array}$ & Doses & $\begin{array}{l}\text { Period of } \\
\text { Study }\end{array}$ \\
\hline $\begin{array}{l}\text { A 13-Week Oral Dose Toxicity Study of } \\
\delta \text {-Aminolevulinic acid Phosphate with } \\
\text { Sodium Ferrous Citrate (SFC) in Rats }\end{array}$ & Rat & p.o. & 91 days & $\begin{array}{l}\text { with SFC (1:0.5) 50, } 125, \\
250 \mathrm{mg} / \mathrm{kg} / \mathrm{day} ; \text { without } \\
\mathrm{SFC} 50,125 \mathrm{mg} / \mathrm{kg} / \text { day }\end{array}$ & June 09-Sep 09 \\
\hline $\begin{array}{l}\text { A 4-Week Oral Dose Safety Study of } \\
\delta \text {-Aminolevulinic acid Phosphate with } \\
\text { Sodium Ferrous Citrate in Human }\end{array}$ & Human & p.o. & 28 days & $\begin{array}{c}\text { 25, 50, 75, (100) } \\
\text { mg/body/day } \\
\text { ALA:SFC }=1: 0.5\end{array}$ & $\begin{array}{c}\text { June 09-Feb } \\
10\end{array}$ \\
\hline $\begin{array}{c}\text { Study on Antidiabetic Effect of Oral } \\
\delta \text {-Aminolevulinic acid (ALA) Phosphate in } \\
\text { Genetically Type } 2 \text { Diabetic Rat (ZDF rat) }\end{array}$ & Rat & p.o. & 28 and 56 days & $\begin{array}{c}2 \mathrm{mg} / \mathrm{kg} / \text { day with } 2.3 \\
\mathrm{mg} / \mathrm{kg} / \text { day SFC }\end{array}$ & July 09-Oct 09 \\
\hline $\begin{array}{l}\text { Evaluation of the effect of } \delta \text {-Aminolevulinic } \\
\text { acid phosphate and sodium ferrous citrate } \\
\text { on basal metabolism of rats }\end{array}$ & Rat & p.o. & $\begin{array}{l}\text { To Be } \\
\text { Determined } \\
\text { (TBD) }\end{array}$ & TBD & TBD \\
\hline $\begin{array}{l}\text { Evaluation of the beneficial effect of supplementary } \\
\text { diet containing } \delta \text {-Aminolevulinic acid phosphate } \\
\text { and sodium ferrous citrate on adults with marginal } \\
\text { diabetes (Proof of Concept Study) }\end{array}$ & Human & p.o. & TBD & TBD & TBD \\
\hline
\end{tabular}

Table 3. The table provides a summary of the toxicity studies done using 5-ALA phosphates. Significant safety is demonstrated.

\begin{tabular}{ccc}
\hline Preclinical and Safety Tests & Dose or Response & \\
\hline Acute oral toxicity & LD $50>200 \mathrm{mg} / \mathrm{kg}$ & Good Laboratory Practice (GLP) \\
Subacute oral toxicity (28 days) & $60 \mathrm{mg} / \mathrm{kg} / \mathrm{day}$ & GLP \\
Chronic oral toxicity (90 days) & $15 \mathrm{mg} / \mathrm{kg} / \mathrm{day}$ & GLP \\
Reversion test with bacteria & negative & GLP \\
$\begin{array}{c}\text { Chromosomal aberration test with } \\
\text { mammalian cells in culture }\end{array}$ & negative & GLP \\
$\begin{array}{c}\text { Reproduction and development toxicity administration } \\
\text { of the drug prior to, and in early stages of, pregnancy } \\
\begin{array}{c}\text { Reproduction and development toxicity administration } \\
\text { of the drug during the period of fetal organogenesis }\end{array}\end{array}$ & $60 \mathrm{mg} / \mathrm{kg} / \mathrm{day}$ & GLP \\
$\begin{array}{c}\text { Reproduction and development toxicity administration } \\
\text { of the drug during the perinatal and lactations periods } \\
\text { Phototoxicity }\end{array}$ & $180 \mathrm{mg} / \mathrm{kg} / \mathrm{day}$ & GLP \\
\hline
\end{tabular}

step 1, 4 subjects in step 2, and 9 subjects in step 3). Total numbers of adverse events were 24 (6 events in step 1, 4 events in step 2, and 14 events in step 3). Symptoms in step 1 included diarrhea (2 events), headache (2), abdominal pain (1), facial swelling (1). Symptoms in step 2 included diarrhea (2 events), queasiness (1), stomach pain (1). Symptoms in step 3 included abdominal pain (4 events), rheumatoid symptoms (4), diarrhea (3), flatulence (2), stiff shoulders (1). All adverse events were selfrecognized subjective symptoms and judged by the Investigator to be unrelated to the study diet intake and to be mild in severity. Some data from laboratory test parameters showed statistically significant changes from baseline. All those changes (mild nausea, headache and GI upset) were relatively mild in severity and were judged by the Investigators to be clinically insignificant. The abnormal tests were the red blood cells, hemoglobin, hematocrit, Mean Corpuscular Volume (MCV). Based on all of the results obtained in this clinical study, it is concluded that the test food supplement given in the tested doses have no safety problems of clinical significance. The other investigations in humans were at lower dosages. The Study on the Safety of Oral ALA Phosphate (Alone and in Combination with Sodium Ferrous Citrate) in Healthy Adults, Protocol No. 19474 June 17, 2008 was submitted by Cosmo Oil Co. Ltd. at the Meguro Medical Clinic, Medical Corporation Yukokai [9]. The Investigator is Hitoshi Suzuki, MD. There were 30 participants that consumed $97.4 \%$ of the additive. The food supplement additive was taken for 4 weeks with a 2 week follow-up. The investigators report no related symptoms and document some statistically significant laboratory changes, but not of clinical significance. The following summarizes these findings. 
Table 4. Finished toxicity \& efficacy studies (Cosmo Oil \& SBI LApromo).

\begin{tabular}{|c|c|c|}
\hline \multicolumn{2}{|c|}{ Type of Study } & Species \\
\hline \multicolumn{3}{|c|}{ Single-Dose Toxicity } \\
\hline \multicolumn{2}{|c|}{$\begin{array}{c}\text { Single-dose Oral Toxicity Study } \delta \text {-Aminolevulinic } \\
\text { acid Phosphate in Rats }\end{array}$} & Rat \\
\hline \multicolumn{3}{|c|}{ Repeat-Dose Toxicity } \\
\hline \multicolumn{2}{|c|}{$\begin{array}{l}\text { A 4-Week Oral Dose Toxicity Study of } \\
\delta \text {-Aminolevulinic acid Phosphate in Rats }\end{array}$} & Rat \\
\hline \multicolumn{2}{|c|}{$\begin{array}{c}\text { A 4-Week Oral Dose Toxicity Study of } \\
\delta \text {-Aminolevulinic acid Phosphate in Rats with a } \\
\text { 4-Week Recovery Period }\end{array}$} & Rat \\
\hline \multicolumn{2}{|c|}{$\begin{array}{c}\text { Analysis of Blood Porphyrin analogs } \\
\text { Concentration in a 13-Week Oral Dose Toxicity } \\
\text { Study of } \delta \text {-Aminolevulinic acid Phosphate in Rats }\end{array}$} & Rat \\
\hline \multicolumn{2}{|c|}{$\begin{array}{c}\text { Analysis of Blood PPIX Concentration in a 13-Week } \\
\text { Oral Dose Toxicity Study of } \delta \text {-Aminolevulinic acid } \\
\text { Phosphate in Rats }\end{array}$} & Rat \\
\hline \multicolumn{2}{|c|}{$\begin{array}{l}\text { Study on the Safety of Oral ALA Phosphate } \\
\text { (Alone and in Combination with Sodium Ferrous } \\
\text { Citrate) in Human Healthy Adults }\end{array}$} & Human \\
\hline \multicolumn{2}{|c|}{ Phototoxicity } & \\
\hline \multicolumn{2}{|c|}{$\begin{array}{l}\text { Photo Irritation Study with } \delta \text {-Aminolevulinic acid } \\
\text { Phosphate in Guinea Pigs }\end{array}$} & Guinea Pig \\
\hline \multicolumn{3}{|c|}{$\begin{array}{l}\text { Laboratory examination parameters and their mean } \\
\text { values showed statistically significant } \mathrm{P} \leq 0.05 \text { changes } \\
\text { from baseline at indicated time points from intervention } \\
\text { group: }\end{array}$} \\
\hline Parameter & \multicolumn{2}{|c|}{ Percent increase or decrease } \\
\hline $\begin{array}{l}\text { Red blood cells } \\
(\times 104 / \mu \mathrm{L})\end{array}$ & $-2.5 \%$ & (week 4) \\
\hline \multirow[t]{2}{*}{ Hemoglobin (g/dL) } & $-3.3 \%$ & (week 4) \\
\hline & $-2.8 \%$ & post week 2) \\
\hline \multirow[t]{2}{*}{ Hematocrit } & $-3.7 \%$ & (week 2) \\
\hline & $-4.2 \%$ & (week 4) \\
\hline $\mathrm{MCV}(\mathrm{fL})$ & $-1.7 \%$ & (week 4) \\
\hline $\mathrm{MCH}(\mathrm{pg})$ & $-1.0 \%$ & (week 2) \\
\hline $\operatorname{HDL}(\mathrm{mg} / \mathrm{dl})$ & $-5.7 \%$ & (week 4) \\
\hline Urinary $\mathrm{pH}$ & $-9.0 \%$ & (week 2) \\
\hline
\end{tabular}

Many parameters resolved over time and the clinical implications of these findings were judged to be without clinical consequence $[3,10]$.

Another investigation conducted to study anemia involved 104 female subjects ages 20 - 65 with Hemoglobin levels $8-12 \mathrm{~g} / \mathrm{dl}$ over a 12 week period. Daily doses of food supplementation were administered and expressed as 5-ALA phosphate/sodium ferrous citrate: 10.0 $\mathrm{mg} / 92.0 \mathrm{mg}$ (high-dose); $5.0 \mathrm{mg} / 46.0 \mathrm{mg}$ (mid-dose); and $2.5 \mathrm{mg} / 23.0 \mathrm{mg}$ (low-dose) [11-13]. This investigation also resulted in no safety problems of clinical significance. A study conducted at the University of Hawaii, John A. Burns School of Medicine (UHJABSOM): The Pre-Diabetes and Supplement Study involved 154 participants divided into three groups. Daily doses of 5-ALA phosphate/sodium ferrous citrate were: $15.0 \mathrm{mg} / 17.2 \mathrm{mg}$ (low-dose), $50 \mathrm{mg} / 57.4 \mathrm{mg}$ (high-dose) and control, over a 12 week period. In 2 hour post-Oral Glucose Tolerance Tests (OGTT), glucose levels declined significantly compared to those not taking the supplement $(p=0.02)$ [1] $\mathrm{HbA1C}$ results were of borderline significance $(p=0.07)$ and no untoward effects were reported [1]. Another study conducted at the UHJABSOM was the Supplement Seep study. This study involved 40 participants divided into two groups a $50 \mathrm{mg}$ intervention and a control, again no adverse events were reported. Lastly, an additional study was conducted at the UHJABSOM, the Supplement and Mood study. This study involved 40 participants divided into 2 groups, a $50 \mathrm{mg}$ intervention group and a control group. There were no adverse events reported. Again, all of these studies had no safety problems of clinical significance $[1,7,14]$.

\section{Conclusion}

None of the investigations document the presence of symptoms or abnormal laboratory results of clinical 
significance. Minor laboratory changes were judged to be not clinically significant. For the study conducted in Hawaii, diarrhea and abdominal pain were incorporated into the informed consent for the Supplement Sleep and Mood Studies and the protocol was modified to add laboratory assessments at 4 and 8 weeks into the study. The University of Hawaii Institutional Review Board approved both investigations. No clinically significant abnormalities were observed in these studies that could be attributed to the food supplement.

\section{Acknowledgements}

Strategic Business Innovator (SBI) Pharmaceuticals Co., Ltd. provided a contract to the John A. Burns School of Medicine at the University of Hawaii at Manoa to conduct studies. Cosmo Oil Co. Ltd., contributed to the creation of this report. The authors from the University of Hawaii were partially supported by grants from the National Institute on Minority Health and Health Disparities U54MD007584 and G12MD007601 from the National Institutes of Health.

The study food supplement was provided by the sponsor. Investigators and authors had full control over the studies and the present manuscript. There is no conflict of interest between any of the Investigators or authors and SBI Pharmaceuticals Co., Ltd. The formulation used in the University of Hawaii studies is available in Japan as a food supplement.

\section{REFERENCES}

[1] B. L. Rodriguez, J. D. Curb, J. Davis, T. Shintani, M. H. Perez, N. Apau-Ludlum, et al., "Use of the Dietary Supplement 5-Aminiolevulinic Acid (5-ALA) and Its Relationship with Glucose Levels and Hemoglobin A1C among Individuals with Prediabetes," Clinical and Translational Science, Vol. 5, No. 4, 2012, pp. 314-320. http://dx.doi.org/10.1111/j.1752-8062.2012.00421.x

[2] A. Gorchein and R. Webber, "Delta-Aminolaevulinic Acid in Plasma, Cerebrospinal Fluid, Saliva and Erythrocytes: Studies in Normal, Uraemic and Porphyric Subjects," Clinical Science (Lond), Vol. 72, 1987, pp. 103-112.

[3] T. Yamamoto, "Technical Reports SBI ALA Promo Co Ltd. Study on the Safety of Oral ALA Phosphate in Healthy Adults," Meguro Medical Clinic, Medical Corporation Yukokai, Contact Research Organization TTC Co. Ltd., Tokyo.

[4] W. R. Chlorophylls, "Encyclopedia of Plant and Crop Science," R. M. Goodman, Ed., Robert M. Goodman
Marcel Dekker Inc., 2004, pp. 258-262.

[5] W. Stummer, U. Pichlmeier, T. Meinel, O. D. Wiestler, F. Zanella, H. J. Reulen, et al., "Fluorescence-Guided Surgery with 5-Aminolevulinic Acid for Resection of Malignant Glioma: A Randomised Controlled Multicentre Phase III Trial," Lancet Oncology, Vol. 7, No. 5, 2006, pp. 392401. http://dx.doi.org/10.1016/S1470-2045(06)70665-9

[6] R. Ritz, G. C. Feigl, M. U. Schuhmann, A. Ehrhardt, S. Danz, S. Noell, A. Bornemann and M. S. Tatagiba, "Use of 5-ALA Fluorescence Guided Endoscopic Biopsy of a Deep-Seated Primary Malignant Brain Tumor," Journal of Neurosurgery, Vol. 114, No. 5, 2011, pp. 1410-1413.

[7] K. A. Morton, P. Kushner, J. G. Straka and B. F. Burnham, "Biosynthesis of 5-Aminolevulinic Acid and Heme from 4,5-Dioxovalerate in the Rat," Journal of Clinical Investigation, Vol. 71, No. 6, 1983, pp. 17441749. http://dx.doi.org/10.1172/JCI110929

[8] T. Yamamoto, "Study on the Safety of Oral ALA Phosphate," Healthy Adults Technical Reports, SBI ALA Promo Co Ltd. Meguro Medical Clinic, Medical Corporation, Yukokai.

[9] H. Suzuki, "Study on the Safety of Oral ALA Phosphate (Alone and in Combination with Sodium Ferrous Citrate)," Contract Research Organization: TTC Co., Ltd., Tokyo, 2008, Healthy Adults Protocol No. 19474.

[10] H. T. Ji, L. T. Chien, Y. H. Lin, H. F. Chien and C. T. Chen, "5-ALA Mediated Photodynamic Therapy Induces Autophagic Cell Death via AMP-Activated Protein Kinase," Molecular Cancer, Vol. 9, 2010, p. 91. http://dx.doi.org/10.1186/1476-4598-9-91

[11] S. Beale, "Biosynthesis of the Tetrapyrrole Pigment Precursor, d-Aminolevulinic Acid, from Glutamate," Plant Physiology, Vol. 93, No. 4, 1990, pp. 1273-1279. http://dx.doi.org/10.1104/pp.93.4.1273

[12] H. Huangchang, "Study on the Safety of Oral ALA Phosphate in Healthy Adults," Study Site: Meguro Medical Clinic MCYROTCL, Tokyo, 2010, Protocol No. 21570.

[13] C. Mingone, S. Gupte, J. Chow, M. Ahmad, N. Abraham and M. Wolin, "Protoporphyrin Generation from Aminolevulinic Acid Elicits Pulmonary Artery Relaxation and Soluble Guanylate Cyclase Activation," American Journal of Physiology-Lung Cellular and Molecular Physiology, Vol. 29, 2006, pp. L337-L344. http://dx.doi.org/10.1152/ajplung.00482.2005

[14] S. Ogura, K. Maruyama, Y. Hagiya, Y. Sugiyama, K. Tsuchiya, K. Takahashi, F. Abe, K. Tabata, I. Okura, M. Nakajima, et al., "The Effect of 5-Aminolevulinic Acid on Cytochrome Coxidase Activity in Mouse Liver," BMC Research Notes, Vol. 4, No. 1, 2011, p. 66. http://dx.doi.org/10.1186/1756-0500-4-66 